in immediately preceding years and notably lower than in 1913, probably because in these two countries the markets were better supplied than formerly and fish had become a more plentiful and cheaper food.

A still more curious and surprising thing is that the adjusted prices of 1937, as compared with those of 1913, were lower in all countries except Scotland, Ireland, and Denmark. In the first two countries fish prices appeared to remain considerably above the 1913 level; and in Denmark, although decreased by about 20 per cent in two years, they still remained above the pre-War level. In all other countries, and most notably in Germany and Holland, fish appears to have been considerably cheaper in 1937 than in 1913. In Table 2, where the prices in recent years are given and also their percentage ratio of the 1913 values, the all but universal reduction in fish prices between 1935 and 1937 is very conspicuous. No explanation of this very remarkable fact is attempted.

From these and many other equally interesting general considerations, the Bulletin proceeds to give more specialized information concerning such matters as the landings of different fishes, and groups of fishes, from the numerous fishing grounds; the shares of the various participating countries in these landings; and even the seasonal fluctuations in the mean monthly landings of certain fishes of special importance, for example, plaice and sole, from the North Sea and elsewhere.

For all those with any interest in fish or fisheries, whether from the scientific or commercial point of view, the Statistical Bulletin is a mine of useful information most attractively presented. Not least among the many harmful results of the present War will be yet another interruption in the continuity of much of the data upon which the Bulletin is based.

\title{
AERIAL, GEOLOGICAL AND GEOPHYSICAL SURVEY OF NORTHERN AUSTRALIA
}

\author{
By Dr. L. Dudley Stamp
}

\begin{abstract}
$\mathrm{F}^{\circ}$ OR roughly a century the development of tropical Australia proceeded in an atmosphere of unqualified optimism. It was almost universally believed that only capital and enterprise were needed to render richly productive of minerals and agricultural wealth the vast untenanted northern half of the continent. Agricultural successes on the wellwatered coast of Queensland were used to discount a dismal succession of failures elsewhere, and a few highly successful mining enterprises caused a willing public to forget many failures. Within the last fifteen years a professor in an Australian university who dared suggest that tropical Australia was far from being an El Dorado and in any event could only be developed by permitting coloured immigrants was so pilloried by the Press that he sought refuge in resignation. But the negligible return for a huge expenditure of public money at last rendered inevitable the conclusion that all was not well, and the long reign of optimism was succeeded by a period of extreme pessimism.
\end{abstract}

In the last few years has come the realization that the whole problem of tropical Australia needs to be examined scientifically and without prejudice, using all the weapons at the command of the modern investigator. In that spirit the three Governments concerned-the Governments of the Commonwealth, Queensland and Western Australia-agreed to inaugurate a survey with the object of seeking new mineral resources in the parts of the continent lying north of $22^{\circ} \mathrm{S}$. $£ 150,000$ was provided-half by the Commonwealth Government, a quarter each by the other two-and it was intended originally to devote three years to the work. It was the first time in the history of Australia that three Governments had pooled their resources for such an investigation. On September 19, 1934, a party of four (Mr. P. B. Nye, executive officer of the Survey, Mr. L. C. Ball, Queensland, Mr. F. G. Forman, Western Australia, and Dr. W. G. Woolnough, Commonwealth geological adviser) set out on a preliminary reconnaissance flight of 12,000 miles to determine areas suitable for investigation. It was agreed that out of more than a million square miles approximately some 10,000 square miles could reasonably be covered in three years, the survey being confined to metallic minerals, particularly gold. Survey work actually began in May 1935 and falls into three parts. Aerial photo. graphy was carried out by the Royal Australian Air Force ; ground surveys by three parties (in Queensland, Northern Territory and Western Australia respectively); geophysical surveys in selected areas were at first carried out under contract by the Electrical Prospecting Company of Sweden (Mr. Sepp Horvath) and later by the Survey staff itself.

The Survey has issued comprehensive progress reports every six months, beginning with a combined one for the whole period ended December 31, 1935. Those for the periods ended December 1935, 1936 and 1937 are particularly valuable as general summaries, and in the last it was pointed out that the work was far from complete and that it was to be continued during 1938. The detailed results are contained in the individual reports, of which there are thirty-nine for Western Australia, thirty-seven for the Northern Territory and thirty-five for Queensland, though all are not yet published. These 111 reports follow a uniform plan : all are issued by the Government Printer, Canberra, they are in foolscap size with appropriate maps, and set out the facts, favourable or unfavourable, on which private enterprise may assess the possibilities. Many are short-a page or two of text-and naturally most deal with ore fields previously known.

A particularly interesting report is Queensland No. 9 -on the Croydon-Golden Gate area which was formerly one of the chief gold producers of Queensland and yielded $£ 3,000,000$ worth of gold before 
being closed down some years ago. It was hoped that geophysical methods would lead to the discovery of new reefs beneath the cover of Cretaceous sandstones, laterite and alluvium. The methods usedelectromagnetic, self-potential, magnetic-are described, and here the electromagnetic was found most successful and disclosed numerous good conductors considered to arise from reef-channels at depths corresponding approximately to water-level. The Survey was empowered to carry out shallow tests but not drilling, and so further work is left to private enterprise.

Report No. 17 of the Northern Territory on the Fletcher's Gully Area, Daly River, may be selected as illustrating a type of history all too common. Traces of gold were discovered in 1905 in almost uninhabited country 100 miles south of Darwin. A 'gold rush' of about thirty miners followed, but in three months only two remained-working stream tin-and the claims were soon abandoned. In 1909 a group of Chinese got 183 ounces of gold by steady work, but in 1910 the area was declared a 'goldfield' and the Chinese had to leave. The field was again abandoned after a few months. In 1912 the Chinese returned. In 1918 a new serious start was made by erecting a battery, but it apparently was never used. In 1926-29 there was a little spasmodic working by a few old Chinese. Now the Survey discloses small sub-horizontal reefs, some possibly with payable values, but does not encourage further work.

In some reports comes the thrill of new discoveries. Queensland No. 12 deals with an area in Cape York Peninsula, proclaimed a goldfield in October 1936 and surveyed in the following months. Even there the old type of prospector had penetrated so long ago as 1878 and may have assessed the true value of a mineral field, whichnow promises to be more important for its iron ore.

It is impossible, in the course of a brief review, to do more than indicate the existence of these valuable reports and to congratulate all concerned on the solid work they have carried out-especially. Sir Herbert Gepp, the director, Messsrs. Ball, Forman and Pye, his executive committee, and Messrs. C. S. Honman, P. S. Hossfeld, K. J. Finucane, R. F. Thyer, E. L. Blazey and their assistants, of the field staff.

\section{BROADCASTING OVER WIRES}

$\mathrm{T}$ HE idea of conveying speech and music programmes over a wire network is by no means new in Great Britain, for so early as 1895, the Electrophone Company provided a service to telephone subscribers by special connexion to theatres, music halls and churches. Until a few years ago, however, no serious development had taken place owing to the indifferent quality of the service, the absence of suitable loud speakers and amplifying equipment, and the lack of public demand resulting from the relatively high cost involved. The introduction and success of radio broadcasting, accompanied by revolutionary developments in technique and equipment, have caused renewed attention to be given to the possibilities of diffusing programmes over wire networks. For some years past a number of relay companies have been re-distributing the ordinary broadcast programmes over special wire network systems to subscribers who prefer this mode of reception to that involving the use of a normal receiver.

On March 30, 1939, the Postmaster-General announced that the Post Office was contemplating the introduction of a system of distributing broadcasting programmes over the line telephone network, as a service additional to that of the existing relay companies (see Nature, April 8, 1939, p. 592). In a paper read before the Wireless Section of the Institution of Electrical Engineers on March 7, Dr. T. Walmsley gave an account of the technical progress made in this subject up to the outbreak of the War, by the Wire Broadcasting Branch of the General Post Office. After referring to the fact that the wire broadcasting system is likely to be relatively free from the various types of interference to which radio broadcasting is subject, the paper presented a detailed consideration of both the principles and the technique involved in distributing over wires at either audio or radio frequencies.

While the audio frequency system of distribution could make use of existing telephone lines, consider- able interference with other telephone circuits would result if the electrical energy were transmitted over the lines at a sufficient level to operate loud-speakers direct. Thus either the energy level must be reduced and an amplifier used on the listener's premises, or a special wire network must be employed. 'The latter system is the more satisfactory and has been more widely used up to date. Two arrangements of the scheme are possible; the first provides a separate pair of wires for each programme from the distribution station to a selector switch at the listener's premises; while the second provides several programmes over one pair of wires to the listener, who, by means of a special switch, is enabled by remote control to select one of several programmes available at the distribution station. Which of the two is the more suitable depends largely upon local conditions, the geographical distribution of the subscribers, and the relative costs of the switching systems and the installation of the necessary lines. The remote switching system has many interesting technical features, which are fully described in the paper.

The chief attraction of the distribution systems involving carrier or radio frequencies lies in the fact that the existing electricity supply or telephone networks may be utilized, with a consequent saving in line plant costs. The fact that the electricity supply networks in Great Britain are connected to a larger number of premises than the telephone network constitutes the chief advantage of their utilization for distribution of programmes at carrier frequencies. This advantage has, however, limitations set by technical problems such as insulation, so more attention has been given to the use of telephone lines for this purpose. By choosing the carrier frequencies to be within the normal radio broadcasting band, the subscriber can conveniently use a normal commercial broadcasting receiver, the various programmes available over the telephone system being selected by tuning the receiver to certain assigned radio 